\title{
T-cell division in human immunodeficiency virus (HIV)-1 infection is mainly due to immune activation: a longitudinal analysis in patients before and during highly active antiretroviral therapy (HAART)
}

Mette D. Hazenberg, James W. T. Cohen Stuart, Sigrid A. Otto, Jan C. C. Borleffs, Charles A. B. Boucher, Rob J. de Boer, Frank Miedema, and Dörte Hamann

In human immunodeficiency virus (HIV)-1 infection, highly increased T-cell turnover was proposed to cause exhaustion of lymphocyte production and consequently development of AIDS. Here, we investigated cell proliferation, as measured by expression of the Ki-67 nuclear antigen, in peripheral blood $\mathrm{CD}^{+}$and $\mathrm{CD}^{+}$lymphocyte subpopulations before and during highly active antiretroviral therapy (HAART). In untreated HIV-1 infection, both the percentage and number of $\mathrm{Ki}-67^{+} \mathrm{CD}^{+}$ and $\mathrm{CD}^{+}+$lymphocytes were significantly increased, compared with values ob- tained from healthy individuals. A more than 10-fold increase in the percentage of dividing naive $\mathrm{CD}^{+} \mathrm{T}$ cells in the blood was found when the number of these cells were below 100 per $\mu \mathrm{L}$.. HAART induced an immediate decline in $\mathrm{Ki}-67$ antigen expression, despite often very low CD4+ T-cell numbers, arguing against increased proliferation being a homeostatic response. After approximately 24 weeks of HAART treatment, a transient increase in the number of proliferating cells was seen, but only in the $\mathrm{CD}^{+}{ }^{+} \mathrm{CD} 27^{+}$memory pool. In the $\mathrm{CD}^{+} \mathrm{T}$-cell compartment, the number of dividing cells was elevated 20 - to 25 -fold. This increase was most notable in the $\mathrm{CD}^{2} 7^{+} \mathrm{CD} 45 \mathrm{RO}^{+}$and CD27- ${ }^{-}$CD45RO ${ }^{+}$ memory $\mathrm{CD}^{+} \mathrm{T}$-cell pool, corresponding with the degree of expansion of these subsets. Reduction of plasma HIV-RNA load by HAART was accompanied by a decrease in numbers and percentages of dividing cells in all CD8 ${ }^{+} \mathrm{T}$-cell subsets. Taken together, our results indicate that peripheral T-cell proliferation is a consequence of generalized immune activation. (Blood. 2000;95:249-255)

๑) 2000 by The American Society of Hematology

\section{Introduction}

Several hypotheses have been presented to explain the loss of $\mathrm{CD}^{+} \mathrm{T}$ lymphocytes, the major hallmark of human immunodeficiency virus (HIV)-1 infection that leads to severe immune depletion and ultimately AIDS and death. The model of high lymphocyte turnover has received considerable attention over the past few years. ${ }^{1,2}$ On the basis of the observation that during the first few weeks of highly active antiretroviral therapy (HAART) the number of $\mathrm{CD}^{+}{ }^{+} \mathrm{T}$ cells increases, it was postulated that HIV-1 infection leads to a rapid turnover of lymphocytes, reflecting a new balance between production and death of lymphocytes. The increased production rate would eventually lead to exhaustion of the $\mathrm{CD}^{+}{ }^{+} \mathrm{T}$-cell renewal capacity and result in $\mathrm{CD}^{+}$lymphocyte depletion. Indeed, in simian immunodeficiency virus (SIV)-infected macaques increased T-cell production was observed $^{3}$; however, there was a parallel rise in the turnover of B cells and NK cells. ${ }^{4}$ Moreover, the highest increase was observed in $\mathrm{CD}^{+} \mathrm{T}$ cells, the compartment that is initially expanded and does not get depleted until very late in the course of HIV-1 infection. . $^{5}$

HIV-induced lymphocyte depletion and subsequent recovery after HAART appeared to be variable when studied at the level of T-cell subsets. Infection with HIV-1 induces an early decline in the number of naive $\mathrm{CD}^{+}$and $\mathrm{CD}^{+}$and memory $\mathrm{CD}^{+}{ }^{+} \mathrm{T}$ lymphocytes. Conversely, the memory and activated $\mathrm{CD} 8^{+} \mathrm{T}$-cell compartments expand initially. Only shortly preceding progression to AIDS, the numbers of these latter cell types fall as well. ${ }^{10-12}$ HAART induces an early rise of memory $\mathrm{CD} 4^{+}$and $\mathrm{CD} 8^{+}$T-cell numbers, accompanied by a slow increase in naive $\mathrm{CD}^{+}$and $\mathrm{CD}^{+}{ }^{+} \mathrm{T}$-cell numbers. ${ }^{13,14}$ From this, it was concluded that different mechanisms are involved in the dynamics of depletion and recovery of the various T-lymphocyte subsets. These mechanisms include interference of HIV with de novo T-cell production capacity ${ }^{15}$ (D. R. Clark et al, submitted for publication) and enhanced sequestration of cells in lymphoid tissues. ${ }^{14,16-18}$ Recently several groups have reported on cross-sectional studies of T-cell production levels. Most of these reports studied total $\mathrm{CD}^{+}$and $\mathrm{CD} 8^{+}$T-cell populations, and did not discriminate between naive and memory subsets. ${ }^{3,7,8,19,20}$

To answer the question whether increased T-cell proliferation could be involved in $\mathrm{CD} 4^{+}$lymphocyte depletion, we measured expression of the Ki-67 antigen in naive and memory CD4 ${ }^{+} \mathrm{T}$-cell subsets in the blood. Furthermore, we investigated the role of T-cell proliferation in the expansion and depletion of naive, memory, and effector $\mathrm{CD}^{+} \mathrm{T}$ lymphocyte subsets. Our approach was longitudinal: cell division rates were studied from the stage of chronic untreated HIV-1 infection up to a year of treatment with HAART.

\section{Materials and methods}

\section{Patients}

To study T-cell turnover before and during antiretroviral treatment, sequential cryopreserved peripheral blood samples from HIV-1 infected
From the Department of Clinical Viro-Immunology, CLB, and the Laboratory for Experimental and Clinical Immunology and Department of Human Retrovirology, Academic Medical Center, University of Amsterdam, Amsterdam; the Department of Internal Medicine, University Hospital Utrecht; the Department of Virology, Eijkman-Winkler Institute, University Hospital Utrecht; and the Department of Theoretical Biology, Utrecht University, Utrecht, The Netherlands.
Reprints: Mette D. Hazenberg, Department of Clinical Viro-Immunology, Plesmanlaan 125, 1066 CX Amsterdam, The Netherlands.

The publication costs of this article were defrayed in part by page charge payment. Therefore, and solely to indicate this fact, this article is hereby marked "advertisement" in accordance with 18 U.S.C. section 1734.

(C) 2000 by The American Society of Hematology 
participants of the CHEESE study were used. Cryopreservation was performed using a computerized freezing device that results in optimal quality of viably frozen cells for functional studies ${ }^{21}$ Frozen blood samples were stored in liquid nitrogen. No differences in Ki-67 expression were found between freshly isolated or frozen cells in a pilot experiment (data not shown). In the multicenter CHEESE study, patients received either zidovudine (Retrovir; $200 \mathrm{mg}, 3$ times daily), lamivudine (Epivir; $150 \mathrm{mg}$, twice daily), and saquinavir soft gel capsules (Fortovase; $1200 \mathrm{mg}, 3$ times daily), or zidovudine, lamivudine, and indinavir (Crixivan; $800 \mathrm{mg}, 3$ times daily). The inclusion criteria for this trial were no previous treatment with antiretroviral therapy, except for AZT $<12$ months, CD4 ${ }^{+}$T-cell count $<$ 500 per $\mu \mathrm{L}$, or HIV RNA $>10000$ copies per $\mathrm{mL}$, or CDC stage $\mathrm{B}$ or C. ${ }^{22}$ Of 60 participants, 16 were selected on the basis of baseline $\mathrm{CD}^{+}{ }^{+} \mathrm{T}$-cell numbers and the availability of frozen peripheral blood mononuclear cell (PBMC) samples. Patients were equally distributed among both therapy arms. Expression of the Ki-67 antigen was analyzed at 5 timepoints: during untreated HIV infection $(\mathrm{t}=0)$ and after $4(\mathrm{t}=4), 12(\mathrm{t}=12), 24(\mathrm{t}=24)$, and $48(\mathrm{t}=48)$ weeks of therapy. As controls, cryopreserved PBMC from 5 HIV-negative blood bank donors were used.

\section{Monoclonal antibodies}

CD4-PerCP, CD8-PerCP, CD45RO-PE mAb, and Streptavidin-APC were obtained from Becton Dickinson (San Jose, CA). Biotinylated CD27 $\mathrm{mAb}$ was purchased from the CLB (Amsterdam, The Netherlands),

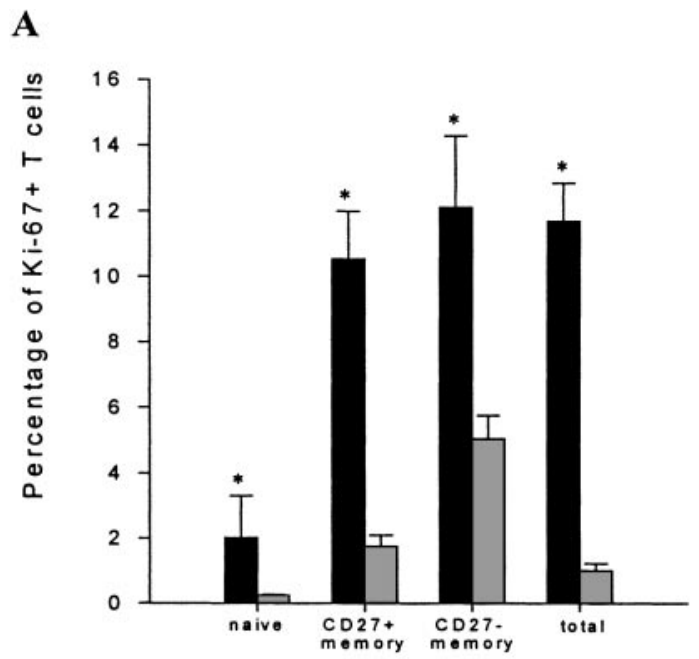

B

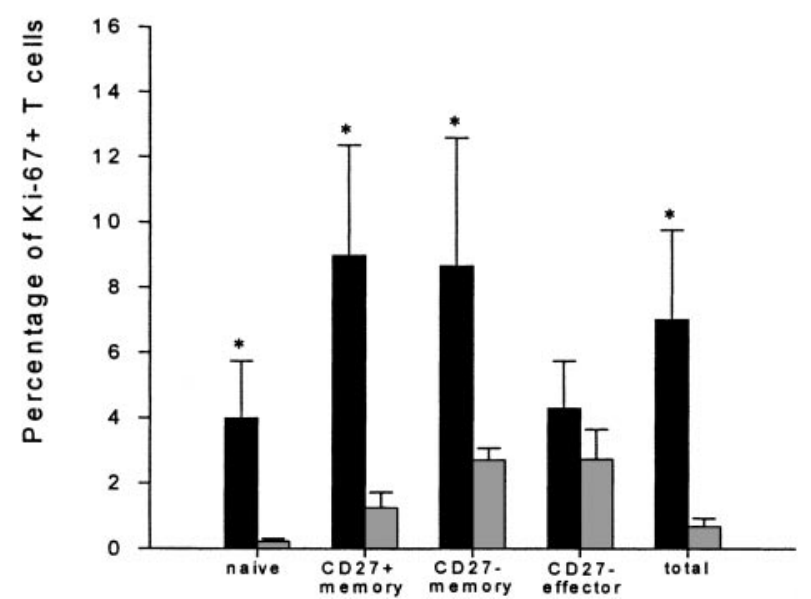

Figure 1. Percentage of $\mathrm{Ki}-67^{+} \mathrm{T}$ lymphocytes within the $\mathrm{CD} 4^{+}(\mathrm{A})$ and $\mathrm{CD} 8^{+}(\mathrm{B})$ peripheral blood T-cell populations of healthy individuals (gray bars) and untreated HIV-infected patients (black bars). An asterisk represents statistical difference compared with control value $(P<.005$; Mann-Whitney $U$ test).
Table 1. Number of Ki-67 antigen expressing cells within the total CD4 ${ }^{+} \mathrm{T}$-cell population and T-cell subsets of untreated HIV-1 infected patients and healthy individuals

\begin{tabular}{llclc}
\hline & \multicolumn{1}{c}{ Naive } & \multicolumn{1}{c}{$\begin{array}{c}\text { CD27 } \\
\text { Memory }\end{array}$} & $\begin{array}{c}\text { CD27 } \\
\text { Memory }\end{array}$ & \multicolumn{1}{c}{ Total } \\
\hline HIV + & $1.6^{*}(0.3-3.5)$ & $13.6^{*}(3.2-26)$ & $5.9^{*}(1-17)$ & $22.8^{*}(4.7-42)$ \\
HIV - & $0.8(0.6-1.4)$ & $5.5(4.3-7.3)$ & $2.7(2.1-3.1)$ & $9.0(7.5-12)$ \\
x-fold increase & 2 & 2.5 & 2.2 & 2.5 \\
\hline
\end{tabular}

Numbers are per $\mu \mathrm{L}$. Median values for the groups, ranges, and the $\mathrm{x}$-fold increase observed in HIV-1 infection compared with the healthy situation are shown.

${ }^{*}$ Significant difference with control values $(P<.05$; Mann-Whitney $U$ test).

and FITC-labeled Ki-67 mAb was purchased from Immunotech (Marseille, France).

\section{Flow cytometry}

$\mathrm{CD}^{+}$and $\mathrm{CD}^{+}{ }^{+}$cells were subdivided into naive $\left(\mathrm{CD} 45 \mathrm{RO}^{-} / \mathrm{CD} 27^{+}\right)$, $\mathrm{CD} 27^{+}$memory $\left(\mathrm{CD} 45 \mathrm{RO}^{+} / \mathrm{CD} 27^{+}\right), \mathrm{CD} 27^{-}$memory $\left(\mathrm{CD} 45 \mathrm{RO}^{+} /\right.$ $\left.\mathrm{CD} 27^{-}\right)$, and $\mathrm{CD}^{2} 7^{-}$effector $\left(\mathrm{CD} 45 \mathrm{RO}^{-} / \mathrm{CD} 27^{-}\right)$cells, as previously described. ${ }^{23,24}$ In contrast to these earlier studies, CD45RA mAb was replaced by $\mathrm{CD} 45 \mathrm{RO} \mathrm{mAb}$ and the definition of the T-cell subsets was adjusted to the used mAb combination. Cell proliferation was studied by measuring expression of the Ki-67 antigen, which is expressed by cells in late G1, S, G2, and M phase of the cell division circle. ${ }^{25-28}$

Cryopreserved peripheral blood mononuclear cells were thawed and incubated with CD4- or CD8-PerCP mAb, CD45RO-PE, and biotinylated $\mathrm{CD} 27 \mathrm{mAb}$. After washing with phosphate-buffered saline (PBS)/0.5\% bovine serum albumin (BSA), cells were incubated with Streptavidin-APC. Red blood cells were lysed and lymphocytes fixated with fluorescenceactivated cell sorter (FACS) Lysing Solution (Becton Dickinson). Subsequent permeabilization was performed by incubating cells with FACS permeabilization buffer (Becton Dickinson), after which cells were stained intracellularly with Ki-67-FITC mAb. Cells were fixed, using Cellfix (Becton Dickinson), and analyzed on a FACS Calibur (Becton Dickinson) with Cellquest software. All incubation steps were performed at $4^{\circ} \mathrm{C}$ for 20 minutes; for fixation and permeabilization, samples were kept at room temperature for 10 minutes.

\section{Viral load}

Plasma viral load was determined with RT-PCR detecting HIV-1 RNA (Roche Amplicor Monitor Standard Assay, Roche Diagnostics, Branchburg, NJ).

\section{Statistical analysis}

Patient characteristics at baseline and after various timepoints during treatment with HAART were compared using Wilcoxon Signed Ranks test and Mann-Whitney U test for comparison with healthy control values. Correlations were calculated using Spearman's correlation coefficients.

\section{Results}

\section{Ki-67 antigen expression in chronic HIV-1 infection}

During chronic untreated HIV-1 infection, both the percentage and the absolute number of $\mathrm{Ki}-67^{+} \mathrm{CD}^{+}$and $\mathrm{CD} 8^{+} \mathrm{T}$ cells was significantly increased (Figure 1, Tables 1 and 2; $P=.001$ ), compared with healthy controls. The percentage of Ki-67 expression was significantly elevated in all subsets $(P<.005)$, except for the $\mathrm{CD} 8^{+} \mathrm{CD} 27^{-}$effector T-cell population (Figure 1 ). Naive $\mathrm{T}$ cells showed a 10- (CD4) to 20- (CD8) fold elevation in Ki-67 ${ }^{+}$ T-cell percentage, and in the memory and effector T-lymphocyte compartment, Ki-67 expression was increased up to 7-fold (Figure 1). When absolute numbers instead of percentages of dividing cells were analyzed, cell proliferation in the $\mathrm{CD} 4^{+} \mathrm{T}$-cell subsets was elevated $<3$-fold, whereas in the $\mathrm{CD} 8^{+}$compartment, 
Table 2. Number of Ki-67 antigen expressing cells within the total CD8 ${ }^{+}$T-cell population and T-cell subsets of untreated HIV-1 infected patients and healthy individuals

\begin{tabular}{lcccc}
\hline & Naive & CD27 ${ }^{+}$Memory & CD27- Memory & CD27- Effector \\
\hline HIV + & $6.9^{*}(1.2-101)$ & $33.9^{*}(8-534)$ & $27.8^{*}(4.1-515)$ & $11.3^{*}(1-195)$ \\
HIV - & $0.4(0.3-1.5)$ & $0.7(0.5-2.1)$ & $0.5(0.1-1.4)$ & $0.5(0.2-1.1)$ \\
x-fold increase & 17.3 & 48.4 & 55.6 & $2.6(1.5-5.1)$ \\
\hline
\end{tabular}

Numbers are per $\mu \mathrm{L}$. Median values for the groups, ranges and the $\mathrm{x}$-fold increase observed in HIV-1 infection compared with the healthy situation are shown.

${ }^{*}$ Significant difference with control values $(\mathrm{P}<.05$; Mann-Whitney $U$ test).

a 20- to more than 50-fold rise was observed (Tables 1 and 2). This increase was most notable in the $\mathrm{CD} 27^{+}$memory and $\mathrm{CD}_{2} 7^{-}$ memory lymphocyte population (see $t=0$, Figure 4B).

The percentage of naive $\mathrm{Ki}-67^{+} \mathrm{CD} 4^{+} \mathrm{T}$ lymphocytes was inversely correlated with the number of naive cells (Figure 2), but did not correlate with plasma viral load (data not shown). Strikingly, only when the number of naive $\mathrm{CD} 4^{+} \mathrm{T}$ cells dropped below 100 cells per $\mu \mathrm{L}$, the proportion of Ki-67 expressing cells in this subset exceeded $2 \%$ (naive CD4 count $>100 / \mu \mathrm{L}: \mathrm{r}=-0.79$, $P=.004$; naive CD4 count $<100 / \mu \mathrm{L}: \mathrm{r}=-0.73, P=.025$; stratification arbitrary). The same overall trend, but not a significant correlation, was observed for the naive CD8 T-cell compartment (Figure 2). The size of the $\mathrm{CD} 27^{+}$memory CD4 ${ }^{+} \mathrm{T}$-cell pool was negatively correlated with the percentage of proliferating cells in this compartment (Figure 2; $\mathrm{r}=-0.68, P=.001$ ). In the $\mathrm{CD}^{+}$ T-cell compartment, the opposite was observed. Here, an increase in the percentage of $\mathrm{Ki}-67$ expressing cells correlated positively with the size of the $\mathrm{CD} 27^{+}$memory T-lymphocyte subset (Figure 2; $\mathrm{r}=0.50, P=.024)$ and the size of the CD27 ${ }^{-}$memory T-cell subset (data not shown; $\mathrm{r}=0.52, P=.016$ ). No correlation was found between the same parameters in the $\mathrm{CD} 4^{+} \mathrm{CD} 27^{-}$memory or the $\mathrm{CD}^{+} \mathrm{CD} 27^{-}$effector T-cell population, or between Ki-67 antigen expression and viral load (data not shown).

\section{Longitudinal analysis of immune recovery during HAART}

Infection with $\mathrm{HIV}-1$ resulted in $\mathrm{CD}^{+}$T-cell depletion and expansion of the $\mathrm{CD}^{+} \mathrm{T}$-cell pool as has been described previously ( $\mathrm{t}=0$ in Figure $4 \mathrm{~A}$ and $\mathrm{B}$ ). Treatment with antiretroviral therapy resulted in a significant decrease of plasma HIV-RNA to

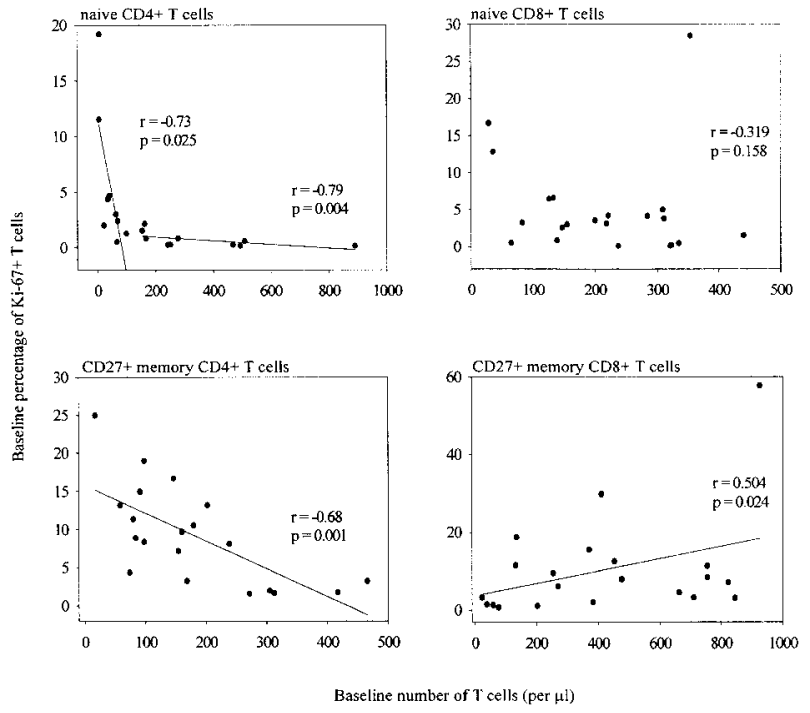

Figure 2. Correlation between the number of $\mathrm{CD}^{+}$and $\mathrm{CD}^{+}$naive or $\mathrm{CD}^{+} 7^{+}$ memory $\mathrm{T}$ cells and the percentage of $\mathrm{Ki}-67^{+}$naive or $\mathrm{CD} 27^{+}$memory cells of untreated HIV-infected and noninfected individuals (Spearman's correlation coefficients). levels below the limits of detection (lower limit of detection 400 RNA copies $/ \mathrm{mL}$ ). In parallel, total numbers of $\mathrm{CD}^{+} \mathrm{T}$ cells increased, and a fall in total numbers of $\mathrm{CD} 8^{+} \mathrm{T}$ lymphocytes was observed (Figure 3). Figure 4A shows that the therapy-induced rise in $\mathrm{CD}^{+}{ }^{+} \mathrm{T}$ cells observed in the first 4 weeks of HAART was accounted for by an increase of both $\mathrm{CD} 27^{+}$memory and naive $\mathrm{T}$ lymphocytes. Stratification of patients into 2 groups, based on their baseline naive $\mathrm{CD}_{4}{ }^{+}$T-cell counts, revealed that the HAARTinduced restoration of the naive subset was better in patients with higher baseline naive $\mathrm{CD} 4^{+} \mathrm{T}$-cell values (Figure 5). After 1 year of treatment, numbers of naive and $\mathrm{CD} 27^{+}$memory $\mathrm{CD} 4^{+} \mathrm{T}$ cells had risen significantly compared with pretreatment levels, but were still lower compared with control levels (Figure 4A, $P<.05$ ). In the same period, as depicted in Figure 4B, the number of naive $\mathrm{CD}^{+} \mathrm{T}$ cells increased. The $\mathrm{CD} 27^{+}$and $\mathrm{CD} 27^{-}$memory and CD27- effector $\mathrm{CD}^{+}{ }^{+}$T-lymphocyte subsets remained significantly expanded, compared with control values $(P<.05)$, despite an initial decrease in cell number that was significant for $\mathrm{CD} 27^{+}$ and $\mathrm{CD} 27^{-}$memory $\mathrm{T}$ cells after 1 and 3 months, respectively $(P<.05)$.

\section{Ki-67 antigen expression during HAART-induced immune recovery}

Immediately on reduction of plasma HIV-RNA load by HAART, the total number (Figure 6A and $\mathrm{B}$ ) and the percentage (data not shown) of $\mathrm{CD}^{+}$and $\mathrm{CD}^{+} \mathrm{Ki}-67^{+} \mathrm{T}$ cells and of $\mathrm{Ki}-67^{+} \mathrm{T}$ lymphocytes in all subsets declined. In the $\mathrm{CD} 4^{+} \mathrm{T}$-cell compartment, this decline was relatively slow when compared with the rapid decline observed in the $\mathrm{CD} 8^{+} \mathrm{T}$-cell population. Furthermore, after 6 months of HAART, a temporary increase in the number of

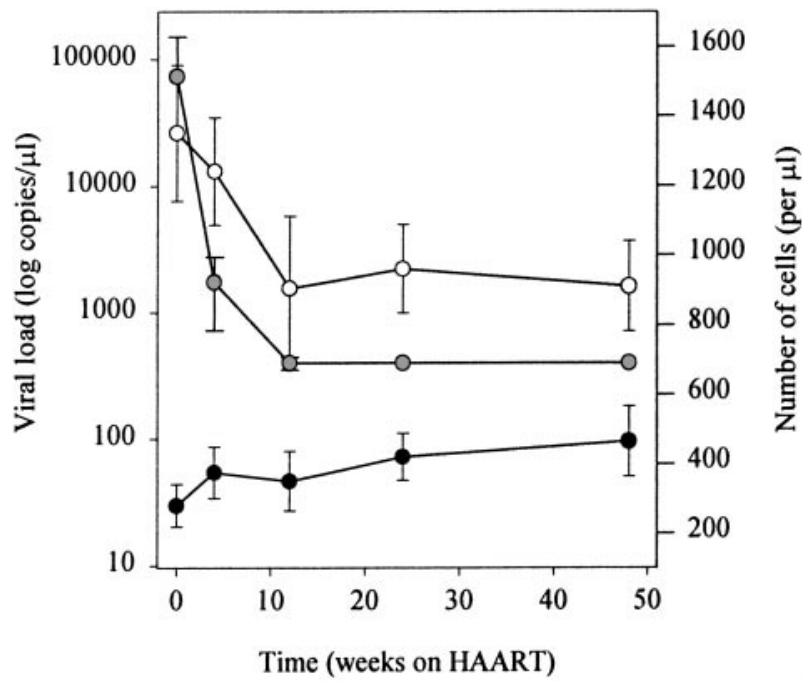

Figure 3. Longitudinal analysis of lymphocyte recovery and plasma HIV-RNA load decline. White dots represent HIV-RNA load, black dots CD4 ${ }^{+} \mathrm{T}$ cells and gray dots $\mathrm{CD} 8^{+} \mathrm{T}$ cells. 
Ki- $67^{+}$lymphocytes was observed in the total $\mathrm{CD}^{+}{ }^{+} \mathrm{T}$-cell population. After 1 year of treatment, numbers of dividing $\mathrm{CD} 4^{+} \mathrm{T}$ cells had returned to normal. Interestingly, the percentage of proliferating $\mathrm{CD}^{+}$naive and $\mathrm{CD} 27^{+}$memory $\mathrm{T}$ lymphocytes was still significantly elevated at that time point $(P<.05$; data not shown). In the $\mathrm{CD} 8^{+} \mathrm{T}$-cell compartment, the steepest decline in the number of $\mathrm{Ki}-67^{+} \mathrm{T}$ cells was observed in the first 4 weeks of treatment (figure 6B; $P<.05$ for $\mathrm{t}=0$ vs $\mathrm{t}=4$ in total $\mathrm{CD}^{+} \mathrm{T}$ cells and in naive, $\mathrm{CD} 27^{+}$and $\mathrm{CD} 27$-memory T-cell subsets). After 1 year, the percentage (data not shown), but not the absolute number of $\mathrm{Ki}-67^{+} \mathrm{CD} 27^{+}$and $\mathrm{CD} 27^{-}$memory and $\mathrm{Ki}-67^{+} \mathrm{CD} 27^{-}$ effector T lymphocytes had returned to normal values $(P<.008)$.

Despite the severe depletion of the naive T-cell pool, the number of $\mathrm{Ki}-67^{+}$naive $\mathrm{T}$ lymphocytes fell immediately on introduction of HAART (Figure 6A and B). Figure 7 depicts data of the individual $\mathrm{Ki}-67$ decline in naive $\mathrm{CD}^{+} \mathrm{T}$ lymphocytes. Reduction of Ki-67 expression was relatively slow in 2 patients who had less than 100 naive $\mathrm{CD} 4^{+} \mathrm{T}$ cells per $\mu \mathrm{L}$ and the highest percentage of dividing naive $\mathrm{CD}^{+}{ }^{+} \mathrm{T}$ cells at baseline. However, as is shown in Figure 8A, no correlation was found between early naive, $\mathrm{CD} 27^{+}$memory or $\mathrm{CD} 27^{-}$memory (data not shown) $\mathrm{CD} 4^{+}$ T-cell recovery with the baseline size of these subsets or with the

A
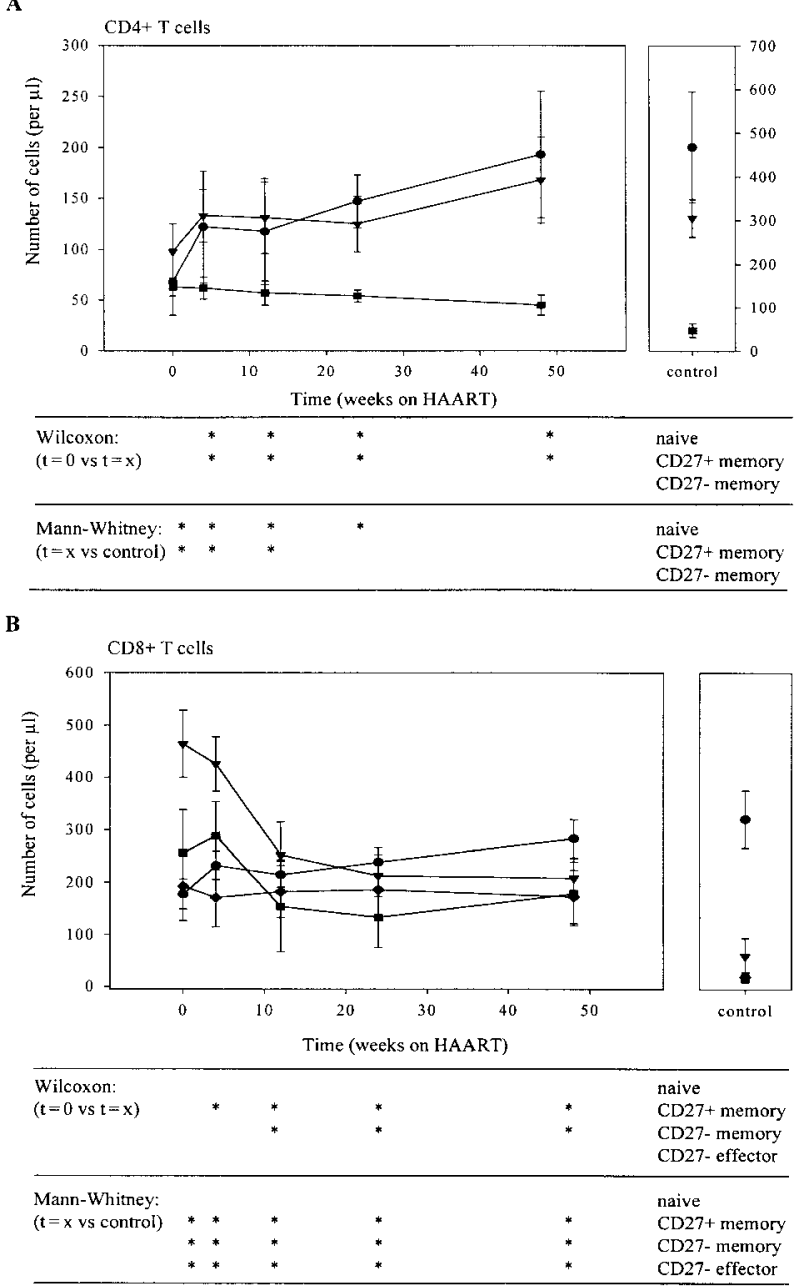

Figure 4. CD4 ${ }^{+}$and $\mathrm{CD}^{+}{ }^{+} \mathrm{T}$-cell subset recovery. Naive (circles), $\mathrm{CD} 27^{+}$memory (triangles), CD27 ${ }^{-}$memory (squares), and CD27- effector (diamonds) lymphocytes within the $\mathrm{CD}^{+}{ }^{+}(\mathrm{A})$ and $\mathrm{CD}^{+}(\mathrm{B}) \mathrm{T}$-cell compartments are shown. Sequential patient values were compared using the Wilcoxon Signed Ranks test, and the Mann-Whitney $\mathrm{U}$ test was used for comparison with healthy individuals $\left({ }^{*} P<.05\right)$.

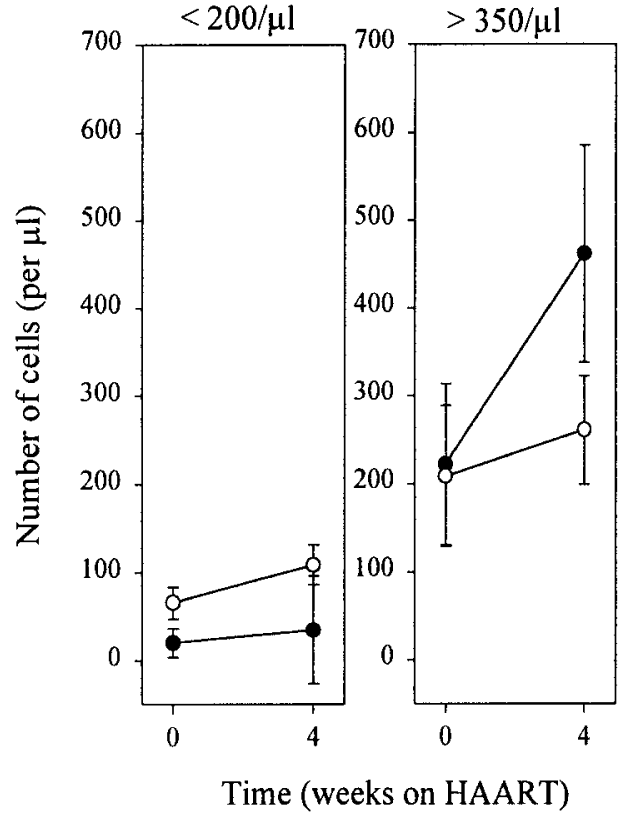

Figure 5. Early recovery of $\mathrm{CD} 4^{+}$naive and $\mathrm{CD} 27^{+}$memory $\mathrm{T}$ lymphocytes. Patients were stratified according to baseline naive T-cell values. Black and white dots represent naive and $\mathrm{CD} 27^{+}$memory cells, respectively.

number of dividing lymphocytes. In the $\mathrm{CD}^{+} \mathrm{T}$-cell compartment (Figure 8B), recovery of the naive subset correlated negatively with its baseline size and with the number of dividing cells within this pool $(\mathrm{r}=-0.511, P=.043$ and $\mathrm{r}=-0.743, P=.001$ respectively). Finally, patients with the most pronounced reduction in size of the $\mathrm{CD} 27^{+}$or $\mathrm{CD} 27^{-}$memory T-cell subset had highest numbers of $\mathrm{CD} 27^{+}$or $\mathrm{CD} 27^{-}$memory $\mathrm{CD} 8^{+} \mathrm{T}$ lymphocytes $(\mathrm{r}=-0.568$, $P=.022$ and $\mathrm{r}=-0.591, P=.016)$, and highest numbers of dividing cells $(\mathrm{r}=-0.776, P=0.000$ and $\mathrm{r}=-0.618, P=.011)$ at baseline. A similar trend, albeit not significant, was observed for the $\mathrm{CD}_{27^{-}}$effector T-cell subset (data not shown).

\section{Discussion}

In this longitudinal study, we measured expression of the Ki-67 antigen, which is taken as a measurement for proliferating cells, in peripheral blood lymphocyte subsets of HIV-1 infected patients. In untreated HIV-1 infection, both the percentage and number of $\mathrm{Ki}-67^{+} \mathrm{CD}^{+}$and $\mathrm{CD} 8^{+}$lymphocytes were significantly increased, compared with values obtained from healthy individuals. These data confirm previous (mainly cross-sectional) studies, , 5,7,8,29 showing that T-cell turnover is increased maximally 2 - to 3 - fold in the $\mathrm{CD}^{+}$, and 6- to 7- fold in the $\mathrm{CD} 8^{+} \mathrm{T}$-cell population. However, when investigating the role of T-cell proliferation in the pathogenesis of HIV-1 infection, lymphocyte subsets rather than total CD4 ${ }^{+}$ or $\mathrm{CD}^{+}{ }^{+} \mathrm{T}$-cell pools should be studied, as naive, memory, and effector $\mathrm{T}$ lymphocytes follow different courses of depletion or expansion. We therefore analyzed changes in expression of the Ki-67 antigen within naive, $\mathrm{CD} 27^{+}$and $\mathrm{CD} 27^{-}$memory and $\mathrm{CD} 27^{-}$effector $\mathrm{CD}^{+}{ }^{+}$and $\mathrm{CD} 8^{+}$lymphocyte populations before and during the course of HAART.

The finding that in untreated HIV-1 infection, the number of proliferating cells was elevated 2 to 3 times in all CD4 ${ }^{+}$T-cell subsets is in good agreement with earlier results demonstrating that the number of apoptotic cells within the CD4 population was 
equally distributed over all subsets. ${ }^{30}$ Together, these data show that, in general, HIV-1 infection affects both naive and memory peripheral blood $\mathrm{CD}^{+}{ }^{+} \mathrm{T}$ cells to a similar degree. The early decrease in the number of naive $\mathrm{CD} 4^{+} \mathrm{T}$ cells could therefore reflect interference of the virus with T-cell renewal capacity rather than with peripheral production of these cells.

The median percentage of dividing naive $\mathrm{CD} 4^{+} \mathrm{T}$ cells was elevated 10 -fold. Higher increases in percentages of Ki-67+ ${ }^{+} \mathrm{CD} 4^{+}$ naive $\mathrm{T}$ cells were observed only when the number of naive cells fell below 100 cells per $\mu \mathrm{L}$. When depletion of lymphocytes would be the driving force for the increase in peripheral naive $\mathrm{CD}^{+}$ T-cell production, one would expect the high rate of cell division to be maintained during treatment with HAART until the number of cells would be normalized. We observed, however, an immediate decline in the number and percentage of $\mathrm{Ki}-67^{+}$naive $\mathrm{CD} 4^{+}$ lymphocytes, although $\mathrm{CD} 4^{+} \mathrm{T}$ cells were still severely depleted. From this we conclude that increased $\mathrm{Ki}-67$ expression in the naive

A

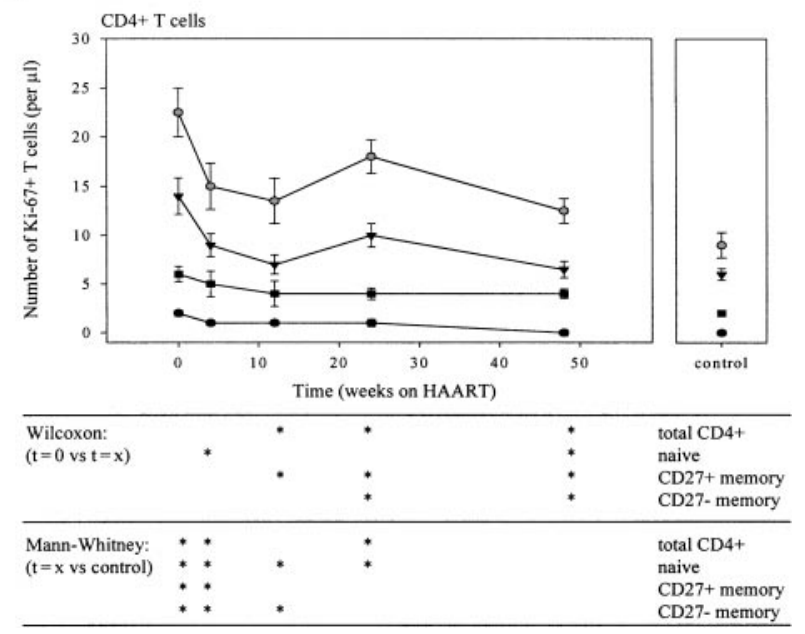

B

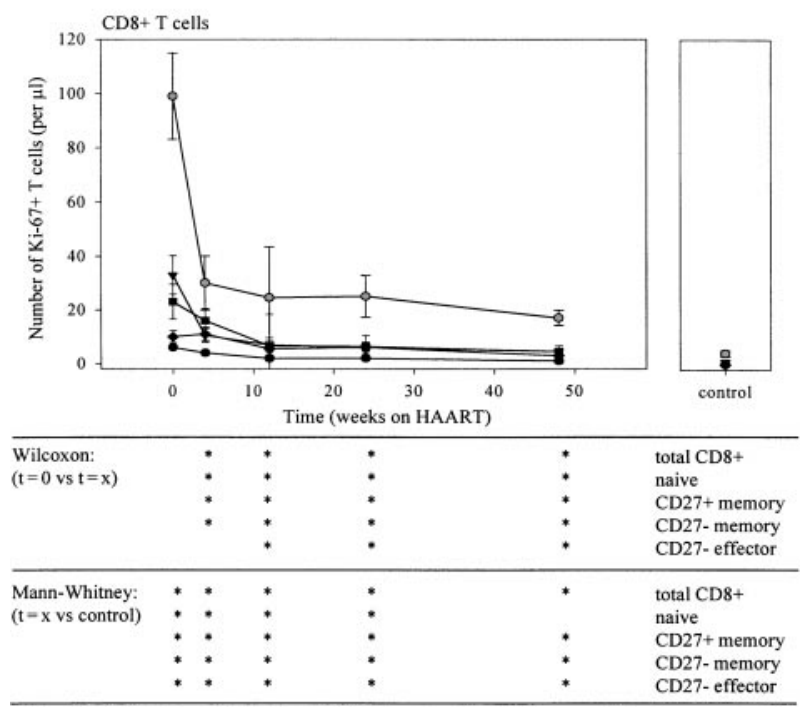

Figure 6. Longitudinal analysis of $\mathrm{Ki}-67$ antigen expression in $\mathrm{CD}^{+}(\mathrm{A})$ and $\mathrm{CD8}^{+}$(B) T lymphocyte subsets and total populations. Decline of the number of total (gray circles), naive (black circles), CD27 ${ }^{+}$memory (black triangles), CD27memory (black squares), and CD27 ${ }^{-}$effector (black diamonds) $\mathrm{Ki}-67^{+} \mathrm{T}$ cells is shown. Sequential patient values were compared using the Wilcoxon Signed Ranks test, and the Mann-Whitney $U$ test was used for comparison with healthy individuals $\left({ }^{*} P<.05\right)$.

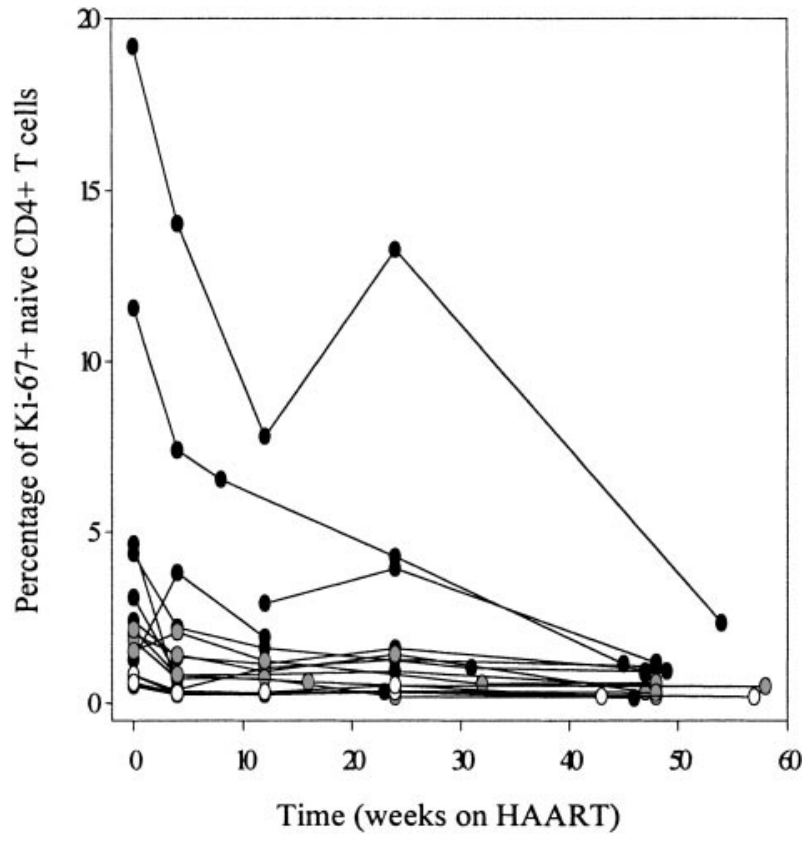

Figure 7. HAART-induced decline in the percentage of proliferating $\mathrm{Ki}-67^{+}$ naive $\mathrm{CD}^{+} \mathrm{T}$ cells. The courses of individual patients are shown. Black dots represent patients with baseline naive $\mathrm{CD} 4^{+} \mathrm{T}$-cell numbers $<300 / \mu \mathrm{L}(n=9)$, gray dots represent individuals with baseline naive CD4 ${ }^{+}$T-cell counts $>300 / \mu \mathrm{L}$ but $<$ $400 / \mu \mathrm{L}(\mathrm{n}=5)$ and white dots represent patients with baseline naive CD4 ${ }^{+}$T-cell count $>600 / \mu \mathrm{L}(\mathrm{n}=2)$.

$\mathrm{CD}^{+}{ }^{+} \mathrm{T}$-cell subset was caused by generalized immune activation rather then being a T-cell homeostatic response to compensate for T-cell depletion.

Furthermore, our data show that the early therapy-induced increase in $\mathrm{CD} 4^{+} \mathrm{T}$ cells is accounted for by a rise in the number of both naive and $\mathrm{CD} 27^{+}$memory $\mathrm{T}$ cells. Our finding that, in both subsets, the percentage and number of dividing lymphocytes decreased during antiretroviral treatment points toward other mechanisms than peripheral expansion involved in recovery of the $\mathrm{CD} 4{ }^{+} \mathrm{T}$-cell pool. It confirms previous reports indicating that in the first 4 weeks of HAART, redistribution of trapped $\mathrm{CD} 27^{+}$cells significantly adds to therapy-induced increase in peripheral blood CD4 ${ }^{+}$T-cell numbers. ${ }^{14,16,17}$

Whereas early restoration of the $\mathrm{CD} 27^{+}$memory $\mathrm{CD} 4^{+} \mathrm{T}$ lymphocyte compartment was fairly constant between patients, recovery of the naive $\mathrm{CD} 4^{+} \mathrm{T}$-cell pool was variable. In patients with less severe depletion of naive $\mathrm{CD}^{+} \mathrm{T}$ cells, a relatively steep increase in the number of naive lymphocytes was observed during the first 4 weeks of HAART, confirming recently published data by Hengel et al. ${ }^{31}$ After this first steep rise, replenishment occurred at a slower rate. Several factors may contribute to restoration of the naive lymphocyte compartment, such as reappearance of preexisting naive $\mathrm{T}$ cells in the peripheral blood, as well as de novo T-cell production from a thymic source. The relative importance of each mechanism in recovery of the immune system needs to be established. Recently, it was reported that thymic production of $\mathrm{T}$ cells increased substantially during HAART. Its dependence on disease progression remains to be studied..$^{15}$

In contrast to the changes occurring in the $\mathrm{CD}_{4}^{+}$T-cell compartment, in the naive $\mathrm{CD}^{+} \mathrm{T}$-cell pool, percentages of dividing cells were elevated regardless of the size of this subset. This points toward a distinct regulation of peripheral T-cell production rates in $\mathrm{CD}^{+}{ }^{+}$and $\mathrm{CD} 8^{+}$cells. The high proliferation 


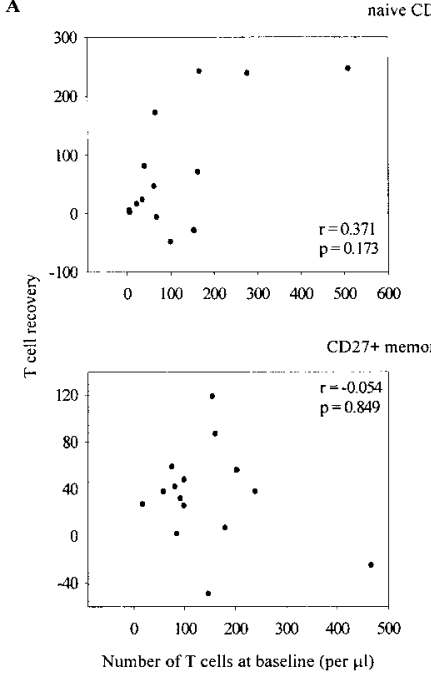

naive $\mathrm{CD} 4+\mathrm{T}$ cells
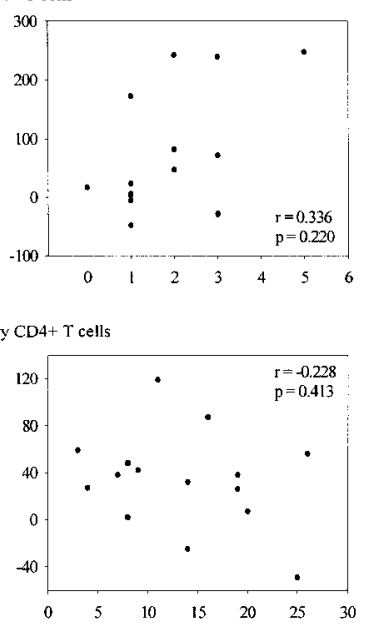

Number of Ki-67+ T cells at baseline (per $\mu \mathrm{l})$
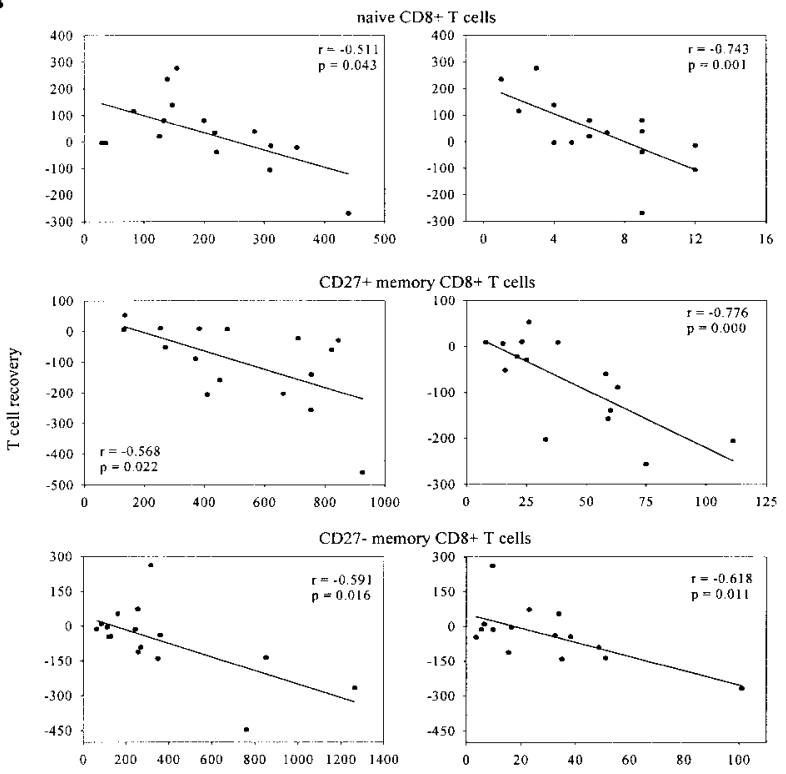

Number of $\mathrm{T}$ cells at baseline (per $\mu \mathrm{l}$ )

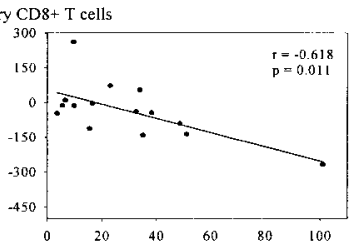

Number of Ki-67+ T cells at baseline (per $\mu$ )

Figure 8. Early recovery of the naive and $\mathrm{CD} 27^{+}$memory $\mathrm{CD}^{+}(\mathrm{A})$ and naive, $\mathrm{CD}^{2} 7^{+}$memory and $\mathrm{CD}^{2} 7^{-}$memory $\mathrm{CD}^{+}(\mathrm{B}) \mathrm{T}$-cell pool. Correlations are shown between T-cell subset recovery in the first 4 weeks of HAART (delta $t=0$ vs $t=4$ ) and baseline size of subset or number of Ki- $67^{+}$cells within each subset (Spearman's correlation coefficients).

rate in the latter population most likely reflects antigen-induced expansion. The degree of expansion of the $\mathrm{CD} 8^{+} \mathrm{T}$-cell subset correlated with the degree of cell proliferation during chronic HIV-1 infection observed in that particular subset. Ongoing antigenic pressure during untreated HIV-1 infection could lead to continuous recruitment of naive $\mathrm{CD} 8^{+} \mathrm{T}$ cells, thereby maintaining increased percentages of Ki-67 antigen expression in this subset. During HAART, both the percentage and the total numbers of dividing cells declined, suggesting that activation-related cell division was the driving force for expansion of the primed subset during chronic HIV-1 infection. The early therapy-induced drop in the number of primed $\mathrm{CD} 8^{+} \mathrm{T}$ cells reached a plateau after 6 months, at which the $\mathrm{CD} 27^{+}$or $\mathrm{CD} 27^{-} \mathrm{CD} 45 \mathrm{RO}^{+}$memory and $\mathrm{CD}_{27}{ }^{-} \mathrm{CD} 45 \mathrm{RO}^{-}$effector $\mathrm{CD}^{+}$lymphocyte pool remained significantly expanded. Although the absolute number of dividing primed

$\mathrm{CD} 8^{+} \mathrm{T}$ cells remained elevated, the percentage of $\mathrm{Ki}-67^{+} \mathrm{T}$ cells within this subset returned to normal values. Using tetrameric HLA-peptide complexes, it has been shown that HAART reduced the frequency of HIV-1 specific cytotoxic T lymphocytes (CTLs) several fold. ${ }^{32}$ The early decline in primed $\mathrm{CD} 8^{+} \mathrm{T}$ cells that we observed could therefore reflect apoptosis of HIV-specific CTLs.

The numbers of dividing cells in healthy individuals found in this study correspond well to the range of earlier results obtained with Ki-67 staining 7,8 and with deuterated glucose labeling of dividing cells. ${ }^{19}$ However, when studying HIV-1 infected patients, in these reports, the average total peripheral blood production of proliferating $\mathrm{CD}^{+} \mathrm{T}$ cells was $5.2 \times 10^{7}$ (range $2.7-8.3 \times 10^{7}$ ) and $10.8 \times 10^{7}$ (range $\left.7.1-12.9 \times 10^{7}\right)$ of $\mathrm{CD}^{+} \mathrm{T}$ cells. These values are lower than those reported in our study $\left(11.4 \times 10^{7}\right.$ [range 2.4-21.0 $\times 10^{7}$ ] and $49.2 \times 10^{7}$ [range 7.0-648.5 $\times 10^{7}$ ], respectively), most likely because of the more advanced disease stage of our patients (see Table 3 ).

After the initial HAART-induced decline, we observed a transient rise in the number of proliferating $\mathrm{CD} 4^{+} \mathrm{T}$ cells after 6 months of therapy, after which these numbers declined further. Because this rise was only due to increased numbers of proliferating $\mathrm{CD} 27^{+}$memory cells, and coincided with dissolvement of the depletion of this subset, it could reflect improvement of the functional capacity of these cells. Indeed, T-cell function, as measured by the in vitro proliferative response to CD3 and CD28 $\mathrm{mAb}$, improved and reached a plateau phase after 6 months of HAART (data not shown). Whereas in our study, the rise in T-cell proliferation did not exceed pretreatment values, in a study reported by Fleury et al, ${ }^{7}$ a clear increase in cell production was seen over baseline after 6 months of HAART. In that report, the baseline $\mathrm{CD}^{+}{ }^{+} \mathrm{T}$-cell counts were relatively high, on average over 600 cells per $\mu \mathrm{L}$. We found the transient rise in numbers of dividing cells to be more pronounced in patients with higher baseline CD4 ${ }^{+}$ T-cell counts (data not shown), pointing toward variances in the stage of HIV-1 infection as the cause of the observed differences.

Taken together, our data are compatible with the idea that most of the elevated cell division and cell death in HIV-1 infection is related to strong persistent immune activation ${ }^{30,33}$ rather than a response to or the cause of lymphocyte depletion. Therefore, alternative factors leading to T-cell decline must be involved in HIV-1 pathogenesis. As has been proposed previously, CD $4^{+} \mathrm{T}$-cell depletion may be due to a diminished capacity for T-cell renewal as a direct or indirect result of HIV-1 infection or could be related to an intrinsically low capacity for renewal in adults, which cannot even compensate for a slightly enhanced T-cell death due to HIV-1 infection and generalized immune activation. ${ }^{34-37}$ Furthermore, we observed a clear distinction between $\mathrm{CD}^{+}$and $\mathrm{CD} 8^{+} \mathrm{T}$ cells, with respect to proliferation rates. A similar dichotomy was found before, when much more cell activation induced death and shortened telomeres were found in the $\mathrm{CD}^{+} \mathrm{T}$-cell fraction. ${ }^{5,38}$ This may fit well with differential requirements for clonal expansion to exercise

Table 3. Baseline numbers of $\mathrm{CD} 4^{+}$and $\mathrm{CD} 8^{+} \mathrm{T}$ lymphocytes in HIV-1 infected patients and healthy individuals

\begin{tabular}{lcc}
\hline & CD4 ${ }^{+}$T Cells & CD8 ${ }^{+}$T Cells \\
\hline HIV - & 824 & 391 \\
$(n=5)$ & $(466-1391)$ & $(101-598)$ \\
HIV + & 280 & 1350 \\
$(n=16)$ & $(50-1060)$ & $(490-3160)$ \\
\hline
\end{tabular}

Median values and ranges are shown. 
$\mathrm{CD}^{+}$helper and $\mathrm{CD}^{+}$effector cell functions. Because cell division diminished rapidly with HAART even when T-cell numbers were still very low, our results suggest that the increased peripheral lymphocyte proliferation is not a homeostatic response to T-cell depletion.

\section{Acknowledgments}

We thank patients and physicians who participated in the CHEESE study, and Dr R. A. W. van Lier for critical reading of the manuscript.

\section{References}

1. Ho DD, Neumann AU, Perelson AS, Chen W, Leonard JM, Markowitz M. Rapid turnover of plasma virions and CD4 lymphocytes in HIV-1 infection. Nature. 1995;373:123-126.

2. Wei X, Ghosh SK, Taylor ME, et al. Viral dynamics in human immunodeficiency virus type 1 infection. Nature. 1995;373:117-122.

3. Rosenzweig M, DeMaria MA, Harper DM, Friedrich S, Jain RK, Johnson RP. Increased rates of $\mathrm{CD}^{+}$and $\mathrm{CD}^{+}{ }^{+} \mathrm{T}$ lymphocyte turnover in simian immunodeficiency virus-infected macaques. Proc Natl Acad Sci U S A. 1998;95:6388-6393.

4. Mohri H, Bonhoeffer S, Monard S, Perelson AS, Ho DD. Rapid turnover of T lymphocytes in SIVinfected rhesus macaques. Science. 1998;279: 1223-1227.

5. Wolthers KC, Wisman GBA, Otto SA, et al. T-cell telomere length in HIV-1 infection: No evidence for increased CD4 ${ }^{+} \mathrm{T}$ cell turnover. Science. 1996;274:1543-1547.

6. Wolthers KC, Otto SA, Wisman GBA, et al. Normal $T$ cell telomerase activity and upregulation in HIV-1 infection. Blood. 1998;93:1011-1019.

7. Fleury S, De Boer RJ, Rizzardi GP, et al. Limited $\mathrm{CD}^{+} \mathrm{T}$-cell renewal in early HIV-1 infection: effect of highly active antiretroviral therapy. Nat Med. 1998;4:794-801.

8. Sachsenberg N, Perelson AS, Yerly S, et al. Turnover of CD4 ${ }^{+}$and CD8 ${ }^{+}$T Lymphocytes in HIV-1 infection as measured by Ki-67 antigen. J Exp Med. 1998;187:1295-1303.

9. Clark DR, De Boer RJ, Wolthers KC, Miedema F. T cell dynamics in HIV-1 infection. Adv Immunol. 1999;73:301-327.

10. Roederer M, Gregson Dubs J, Anderson MT, Raju PA, Herzenberg LA, Herzenberg L. CD8 naive T cell counts decrease progressively in HIVinfected adults. J Clin Invest. 1995;95:2061-2066.

11. Roederer M. T cell dynamics of immunodeficiency. Nat Med. 1995;1:621-622.

12. Margolick JB, Mu-Oz A, Donnenberg AD, et al, for the Multicenter AIDS Cohort Study. Failure of Tcell homeostasis preceding AIDS in HIV-1 infection. Nat Med. 1995;1:674-680.

13. Autran B, Carcelain G, Li TS, et al. Positive effects of combined antiretroviral therapy on CD4 $\mathrm{T}$ cell homeostasis and function in advanced HIV disease. Science. 1997;277:112-116.

14. Pakker NG, Notermans DW, De Boer RJ, et al. Biphasic kinetics of peripheral blood T cells after triple combination therapy in HIV-1 infection: a composite of redistribution and proliferation. Nat Med. 1998;4:208-214.
15. Douek DC, McFarland RD, Keiser PH, et al. Changes in thymic function with age and during the treatment of HIV infection. Nature. 1998;396: 690-695.

16. Kelleher AD, Carr A, Zaunders J, Cooper DA. Alterations in the immune response of human immunodeficiency virus (HIV) infected subjects treated with an HIV-specific protease inhibitor, Ritonavir. J Infect Dis. 1996;173:321-329.

17. Bucy RP, Hockett RD, Derdeyn CA, et al. Initial increase in blood CD4 ${ }^{+}$lymphocytes after HIV antiretroviral therapy reflects redistribution from lymphoid tissues. J Clin Invest. 1999;103:13911398.

18. Wang L, Chen JJY, Gelman BB, Konig R, Cloyd MW. A novel mechanism of CD4 lymphocyte depletion involves effects of HIV on resting lymphocytes: induction of lymph node homing and apoptosis upon secondary signaling through homing receptors. J Immunol. 1999;162:268-276.

19. Hellerstein M, Hanley MB, Cesar D, et al. Directly measured kinetics of circulating $T$ lymphocytes in normal and HIV-1 infected humans. Nat Med. 1999;5:83-89.

20. Zhang ZQ, Notermans DW, Sedgewick G, et al. Kinetics of $\mathrm{CD} 4^{+} \mathrm{T}$ cell repopulation of lymphoid tissues after treatment of HIV-1 infection. Proc Natl Acad Sci U S A. 1998;95:1154-1159.

21. Bom-van Noorloos AA, Van Beek AAM, Melief CJM. Cryopreservation of cells for immunological typing of non-Hodgkin lymphomas. Cancer Res. 1980;40:2890-2894.

22. Cohen Stuart JWT, Schuurman R, Burger D, et al. Randomized trial comparing saquinavir soft gelatin capsules versus indinavir as part of triple therapy (CHEESE study). AIDS. 1999;13:F53F58.

23. Hamann D, Baars PA, Rep MHG, et al. Phenotypic and functional separation of memory and effector human CD8 ${ }^{+}$T cells. J Exp Med. 1997; 186:1407-1418.

24. Baars PA, Maurice MM, Rep M, Hooibrink B, Van Lier RAW. Heterogeneity of the circulating human $\mathrm{CD} 4^{+} \mathrm{T}$-cell population: further evidence that the CD4 ${ }^{+}$D45RA-CD27- -cell subset contains specialized primed cells. J Immunol. 1995;154:17-25.

25. Gerdes J, Lemke H, Baisch H, Wacker H-H, Schwab U, Stein H. Cell cycle analysis of a cell proliferation-associated human nuclear antigen defined by the monoclonal antibody Ki-67. J Immunol. 1984;133:1710-1715.
26. Gerdes J, Schlueter L-LC, Duchrow M, et al. Immunobiochemical and molecular biologic characterization of the cell proliferation-associated nuclear antigen that is defined by monoclonal antibody Ki-67. Am J Pathol. 1991;138:867-873.

27. Schwarting R, Gerdes J, Niehus J, Jaeschke L, Stein $\mathrm{H}$. Determination of the growth fraction in cell suspensions by flow cytometry using the monoclonal antibody Ki-67. J Immunol Meth. 1986;90:65-70.

28. Bruno S, Darzynkiewicz Z. Cell cycle dependent expression and stability of the nuclear protein detected by Ki-67 antibody in HL-60 cells. Cell Prolif. 1992;25:31-40.

29. Wolthers KC, Noest AJ, Otto SA, Miedema F, DeBoer RJ. Normal telomere lengths in naive and memory CD4+ T cells in HIV-1 infection: a mathematical interpretation. AIDS Res Hum Retroviruses. 1999;15:1053-1062.

30. Meyaard L, Otto SA, Keet IPM, Roos MThL, Miedema F. Programmed death of T cells in HIV-1 infection: no correlation with progression to disease. J Clin Invest. 1994;93:982-988.

31. Hengel RL, Jones BM, Kenndey MS, Hubbard MR, McDougal JS. Lymphocyte kinetics and precursor frequency-dependent recovery of CD4 ${ }^{+}$ CD45RA ${ }^{+} \mathrm{CD} 6 \mathrm{~L}^{+}$naive $\mathrm{T}$ cells following tripledrug therapy for HIV type 1 infection. AIDS Res Hum Retroviruses. 1999;15:435-443.

32. Ogg GS, Jin X, Bonhoeffer S, et al. Quantitation of HIV-1-specific cytotoxic T lymphocytes and plasma load of viral RNA. Science. 1998;279: 2103-2106

33. Grossman Z, Herberman RB, Dimitrov DS. T cell turnover in SIV infection. Science. 1999;284:555a

34. Wolthers KC, Schuitemaker H, Miedema F. Rapid CD4 ${ }^{+}$T-cell turnover in HIV-1 infection: a paradigm revisited. Immunol Today. 1998;19:44-48.

35. Clark DR, De Boer RJ, Wolthers KC, Miedema F. T cell dynamics in HIV-1 infection. Adv Immunol. 1999;73:301-327

36. Hazenberg MD, Clark DR, Miedema F. Tilted balance of T cell renewal in HIV-1 infection. AIDS Rev. 1999;1:67-73.

37. Rowland-Jones S. HIV infection: where have all the T cells gone? Lancet. 1999;354:5-7.

38. Meyaard L, Otto SA, Jonker RR, Mijnster MJ, Keet RPM, Miedema F. Programmed death of T cells in HIV-1 infection. Science. 1992;257:217-219. 